\title{
Reflexões sobre a metodologia na pesquisa em Ortopedia e Traumatologia
}

\author{
Thinking on Orthopedics and Traumatology Research Methodology
}

\author{
WILLIAM Dias BeLANGero'
}

"Contra o positivismo que pára perante os fenômenos e diz:

'Há apenas fatos', eu digo: 'Ao contrário, fatos é o que não há: há apenas interpretações' "

(Nietzche)

Seguindo a tendência geral de expansão do conhecimento, a produção científica da área médica tem se ampliado intensamente nas últimas décadas, tornando exaustiva a atualização permanente do conhecimento. No entanto, se o número de informações cresce vertiginosamente, a aquisição destas também tem sido intensamente facilitada pelos meios atuais de comunicação via internet.

Este ritmo de desenvolvimento parece ser paralelo à idéia da medicina Baseada em evidência, que foi concretizada em 1992 por Dr. lain Chalmers em Oxford (UK), com a criação da "Colaboração Cochrane", que tem como objetivo realizar, auxiliar e disseminar revisões sistemáticas de intervenções em saúde.

Este tipo de abordagem permite que se avalie claramente a eficácia de estudos realizados previamente, selecionados por critérios de validade, mas que não puderam chegar isoladamente a conclusões definitivas por terem casuística insuficiente. Assim, adicionando-se casuística de estudos diferentes, mas comparáveis, e aplicando-se rigorosos critérios estatísticos, podem ser obtidas conclusões confiáveis que resultarão em recomendações definitivas de conduta. o conhecimento deste metodologia de trabalho estimula por um lado a realização de estudos prospectivos de boa qualidade científica e, por outro, a utilização deste método como ferramenta de grande potência na definição de condutas ainda questionáveis.

Surge então a questão de como proceder para se obter resultados de boa qualidade metodológica na área cirúrgica, onde os estudos prospectivos, randomizados, com grupo controle, são normalmente impraticáveis do ponto de vista ético. Por outro lado, os estudos retrospectivos têm pouca possibilidade de se tornarem fonte de resultados confiáveis. isto acontece porque a casuística não é conduzida segundo objetivos pr[é-determinados, sendo sempre passível de crítica pela subjetividade, mesmo que não intencional, da seleção dos casos e da análise dos resultados. estes estudos, mesmo quando realizados com grande casuística, têm sido considerados de nível científico insuficiente para garantir uma recomendação terapêutica. Desta forma, todos os esforços

\begin{abstract}
"Watching the positivism, that faces phenomena and says:
'There are only facts', I say: 'There aren't facts. There are interpretations'."
\end{abstract}

(Nietzche)

Following the general tendency of growth of knowledge, scientific production in medical area is intensively growing during the last decades, making constant updating to be exhaustive.

However, if the amount of information is growing in a vertiginous fashion, gathering them is also tremendously easier by means of Internet progress.

This pattern of development looks to be parallel to the Evidence Based Medicine idea, which was brought to be concrete in 1992 by Dr. lain Chalmers from Oxford (UK), through the "Cochrane Cooperation" foundation, which aims to perform, support and divulge systematic reviews of health interventions.

This kind of approach allows to clearly evaluate the efficacy of previously performed studies, selected by validation criteria but which could not reach a definite conclusion due to insufficient number of cases. So, by adding the number of cases from different but comparable studies, and by the application of rigorous statistic criteria, trustful conclusion can be drawn, which will result in clear conduct recommendations. Knowledge of the working methodology from one side, stimulates performing prospective studies with high quality scientific standards, and on the other hand, the use of this method as a potent tool in defining still questioned conducts.

Then, comes the question of how getting high quality surgical studies, in terms of methodology. In this area, prospective, controlled and randomized studies are usually ethically not possible. On the other hand, retrospective studies have low possibilities of giving trustful results. This happens because the case studies are not conducted according to pre-determined objectives, being always subject to criticism due to its subjectivity, even not intentional, in case selection and results analysis.

These studies, even when performed with large number of cases, use to be considered of an insufficient scientific level to warrant a therapeutic recommendation. Thus, every effort should be driven to an hypothesis development be always performed through a prospective study. Even though it is not possible to comply to all desired methodological aspects, it is possible to improve quality

\footnotetext{
1 - Prof. Dr. William Dias Belangero 
deveriam ser dirigidos para que o desenvolvimento de uma hipótese fosse realizado sempre através de estudos prospectivos. Mesmo não sendo possível observarem-se todos os critérios metodológicos ideais, é possível melhorar a qualidade dos resultados seguindo algumas estratégias, que serão descritas a seguir.

O primeiro passo em qualquer pesquisa científica é a definição do tema e dos objetivos gerais e específicos. Se o pesquisador estiver inserido em um grupo com linha de pesquisa, provavelmente as bases teóricas e os questionamentos relativos ao tema da linha já serão de domínio do grupo e, assim, os objetivos serão decorrência natural dos estudos anteriores. No entanto, quando não for este o caso, o pesquisador deverá realizar ampla revisão da literatura com a finalidade de buscar os aspectos polêmicos, ou ainda não definidos, que sustentem a relevância da pesquisa e orientem na definição dos objetivos. Após esta fase, deve-se definir a população e o método a ser empregado para se atingir os objetivos propostos. Não é raro se encontrar publicação que simplesmente informa o número de pacientes estudados durante um determinado período sem, no entanto, fazer referência clara não só ao universo de onde estes foram retirados, como também dos critérios utilizados na inclusão e/ou exclusão dos mesmos.

A definição do tamanho da amostra é outra variável pouco considerada e muitas vezes estimada sem critérios. A rigor, ela deveria ser estimada previamente, tendo em conta o tipo do procedimento, a variabilidade dos resultados e, quando necessário, dever-se-ia lançar mão de estudos estatísticos para a sua definição. Se o resultado deste cálculo atingir valores impraticáveis, ou impossíveis de serem atingidos em um período de estudo viável, o pesquisador poderá optar por realizar um projeto com perspectivas duvidosas, ou propor a composição conjunta da casuística com outro serviço. esta última opção deverá prever ampla discussão de todo o protocolo, com ênfase na técnicas cirúrgica, na experiência prática dos profissionais envolvidos e na análise dos resultados obtidos em serviços distintos.

Vale ressaltar que a análise estatística é, via de regra, importante, principalmente quando as diferenças não são evidentes, podendose até pressupor que esta ferramenta acabe sendo tão mais necessária quanto pior for o planejamento inicial do estudo. Nos trabalhos que envolvem o fator técnico, representado pela habilidade, experiência do cirurgião e até condições materiais da instituição, deve-se ter em mente que estas variáveis podem ser minimizadas com o aumento da casuística, com o treinamento prévio em animais ou em cadáveres. É óbvio que se no estudo existirem cirurgiões com diferentes graus de experiência, ou que estejam em níveis distintos da curva de aprendizagem da técnica, isto deve ser mencionado na metodologia e pesado na análise dos resultados.

Do ponto de vista científico, o relato dos resultados obtidos em função de escalas-padrão ou de comparações com o préoperatório, têm menor valor do que quando estes são definidos em função de metas previamente estabelecidas. A tendência atual é que esta meta leve em consideração não apenas o resultado do procedimento ortopédico, mas também a repercussão deste na qualidade de vida e na readaptação do paciente ao meio sócioeconômico. Assim, outros critérios devem ser considerados para que se possa julgar com mais subsídios se o procedimento, além de ter sido bom para o "fêmur", foi também eficaz para o paciente. Como por exemplo pode-se citar as cirurgias realizadas nas crianças com malformações congênitas que, muitas vezes, têm como única and results by following some strategies as follows.

The first step in any scientific research is to define theme and objectives, both general and specific. If the researcher is part of a group with a defined line of research, the theoretical basis and questioning related to the theme will probably be part of the group knowledge, and so the objectives are naturally driven by previously performed studies. However, when this doesn't happens, the researcher should proceed a wide literature review aiming to find polemical aspects, or those not yet defined, which could support the relevance of the research and help in objectives definition.

After this phase, the population and method should be chosen. It is not rare to find papers that simply inform the number of patients studied during a given period, without clearly reporting where they came from as well as the inclusion and exclusion criteria.

The sample size definition is also seldom considered, and frequently considered without criteria. As a matter of fact, it should be previously estimated, considering the kind of procedure, the variability of results and, when necessary, statistic studies should be used to its election. If the results of this calculation reach not feasible figures, or is impossible to be achieved in a reasonable time of study, the researcher will be able to choose between performing a study with doubtful perspectives or to propose multi-center study. This last option should anticipate a wide protocol discussion, emphasizing surgical technique, and the practicing experience of the involved professionals, and the analysis of the results from different services.

It is worthy to be stressed that statistic analysis is usually important, mainly when differences are not evident. It can even be considered that this tool would be more necessary the worst is the initial study planning. In works that involve technical factors as those represented by ability, surgeon experience and even material environment of the institution, it should be kept in mind that these variables can be minimized by increasing the sample size, and previous training in animals or cadaver. It is obvious that if surgeons of different skill levels participate in the study, or in different steps of the learning of the technique, this should be mentioned in the methodology and considered in result analysis.

From a scientific point of view, reporting results from pattern-scales or comparisons to the pre-operative period are less valued than if this is performed according to pre-established goals. Current trend is that this goal not only evaluates the result of the orthopedic procedure, but also its impact over quality of life and rehabilitation of the patient to social-economic environment. So, other criteria should be took into consideration to allow judging with more subsides if the procedure was good for the "femur" or was also good for the patient him/ herself. For instance it could be mentioned the surgical procedures performed in children with congenital malformation, which frequently have as single objective to preserve the limb with a doubtful utility without considering the high psychological and social costs of the treatment.

The use of a control group brings a higher quality and makes the research more trustful, since it is rare that these studies can be randomized, and will never be double blind.

On the other hand, in this specialty it is also impossible to use an ideal control group, which is that where a patient is not treated. The alternative would be to use a "historical control group", which is however subject to criticism due to not including patients with the same conditions as those selected for the current study, and for having been performed in a different historic moment. On the other hand, if the objective is to compare results obtained from different treatment techniques over the same disease, concomitant studies 
finalidade a manutenção do membro com função discutível sem considerar o elevado custo psíquico social do tratamento.

A utilização do grupo controle confere maior qualidade e confiabilidade no resultado da pesquisa, já que raramente estes estudos podem ser randomizados a nunca são duplo cego. Por outro lado, nessa especialidade também é impossível utilizar-se do grupo controle ideal, que é aquele no qual o paciente é acompanhado sem ser submetido ao tratamento. A alternativa que pode ser adotada é a de se empregar o "grupo controle histórico" que, no entanto, está sujeito a crítica por não incluir pacientes com as mesmas condições de seleção do estudo atual, além de ter sido realizado em um outro momento histórico. Por outro lado, se o objetivo for comparar os resultados obtidos através de diferentes técnicas de tratamento sobre uma mesma doença, podem ser realizados estudos concomitantes em uma ou em mais instituições, observando-se os critérios quanto à seleção dos casos e análise dos resultados. Esta prática, pouco utilizada em nosso meio, deveria ser estimulada, visto que traria benefício a todos os grupos envolvidos, que poderiam produzir estudos com maior aceitação e penetração no meio científico.

Para se obter uma análise neutra e imparcial dos resultados, pode-se também solicitar o auxílio de outros especialistas que não tiveram participação ativa na fase de seleção ou na fase de intervenção do estudo.

Ainda com relação aos resultados, a perda do acompanhamento clínico motivada pelas características migratórias da população, pelas condições sócio-econômicas, pelas grandes distâncias do nosso território, entre outras, devem sempre que possível ser diferenciadas das perdas produzidas pelos maus resultados. É óbvio que quanto maior for a perda da população inicial, mais comprometido ficará o estudo e suas conclusões. Cabe ao pesquisador o uso do seu senso crítico e, principalmente, dos seus princípios, para que não existam dúvidas sobre a realidade dos dados. a análise final, se feita em função dos pacientes ou do número de casos, deve ser definida no início do estudo para se evitar tendenciosidade. A influência da perda de casos pode ser minimizada pelo uso de tabelas de sobrevivência e pelo tempo de seguimento, que demonstrarão o cuidado e a visão crítica do pesquisador. Por fim, deve-se ter em mente que nesta fase nenhum valor de significância resiste a uma metodologia mal feita. E o encontro do p. 0,01 não pode cegar o leitor dos aspectos básicos que construíram todo o estudo.

A discussão dos resultados deverá ser feita em função dos dados atualizados da literatura, enfatizando os aspectos de originalidade e, principalmente, analisando os maus resultados, já que as suas causas sempre são os determinantes mais importantes na revisão e modificação dos procedimentos estudados.

Cercando-se do maior número possível de critérios, pode-se obter, mesmo em estudos não controlados, resultados de boa qualidade científica. deve-se ter em mente que por trás de todo estudo há, além da curiosidade científica, o objetivo da sua divulgação e da aplicação dos seus resultados para o bem-estar do paciente, que é o fecho do ciclo do pesquisador da área clínico cirúrgica.

Para finalizar, as reflexões apresentadas só poderão ter repercussão na medida que os editores e os revisores das publicações científicas exijam qualidade metodológica nos trabalhos aceitos para divulgação. Além disso, fica a sugestão de que este assunto, tão importante para o desenvolvimento com qualidade desta área médica, seja tema a ser amplamente abordado nos encontros científicos da nossa especialidade. could be performed at one or more institutions, taking into consideration the selection criteria and analysis of results. This practice is not very much used among us, and should be stimulated due to bringing benefits to all involved groups that could have a better accepted study. In order to have a sensible and impartial analysis of the results, it could also be requested help from other specialists not actively involved in the selection and intervention parts of the study.

Still considering the results, loosing follow-up due to migratory aspects of population, and social-economic conditions or due to distance, should be differentiated form those from bad results. It is clear that the bigger the loose of initial population, the more compromised is the study and its conclusions. It is up to the investigator to use his/her common sense and principles making sure that no doubt can be raised on the accuracy of the data. Final analysis, whether it is done considering patients or number of cases, has to be previously chosen to avoid bias. Influence of loosing cases can be minimized by using survival tables and time of follow-up, that will display the critical vision and care of the investigator.

Last, it should be kept in mind that in this phase no significance level can resist to a poor methodology, and finding a p 0.01 can not blind the reader to the basic aspects building all the study up.

Results discussion should be performed considering current literature data, emphasizing aspects of originality and specially analyzing the bad results, since their causes will always be the most important determinant of studied procedures review and modification.

By complying to the largest number of criteria it could be obtained, even in non-controlled studies, results that are of scientifically good quality. It should be kept in mind that, behind every study there is, additionally to scientific curiosity, the objective of divulgation and the use of its results for patient's welfare, which is the final goal of the researcher in the clinical and surgical area.

The above considerations will only bring effective results when editors and reviewers of scientific journals demand methodological quality from the papers accepted for publication.

Besides this, we suggest that this subject, so important for a quality development of this medical area, becomes a major theme in scientific meeting or our specialty.

\section{REFERÊNCIA}

- ATAlLAH, A.N. \& CASTRO, A.A.: Medicina baseada em evidencias: o elo entre a boa ciência e a boa prática clínica www.epm.br/cochrane/ebm.htm, 29/03/2000

- GARTLAND, J.J.: Orthopaedic clinical research. J. Bone Jt. Surg., 70(A) 9: 1357-1371, 1988

- MURRAY, D.W.; BULSTRODE, C.J.K. \& CAN, A..: Survival analysis of joint replacements. J. Bone Jt. surg, 75(B): 697-705, 1993.

- PYNSENT, P.B.; FAIRBANK, J.C.T \& CAN, A.J.: Assessment methodology in orthopaedics. Butterworth Heinemann, 1997. 